\title{
IMPLEMENTASI PEMBELAJARAN JIGSAW UNTUK MENINGKATKAN KOLABORASI PESERTA DIDIK MELALUI PENDIDIKAN PANCASILA DAN KEWARGANEGARAAN
}

\author{
Zaenul Slam \\ Universitas Islam Negeri Syarif Hidayatullah, Indonesia \\ Email: zaenul_slam@uinjkt.ac.id
}

\begin{abstract}
ABSTRAK
Dalam praktik pembelajaran di kelas, banyak guru menggunakan metode dan suasana pembelajaran yang dianalogikan dengan kegiatan menabung dan sistem kompetisi, maka untuk mengatasi permasalahan tersebut, diterapkan pembelajaran jigsaw untuk meningkatkan keterampilan kolaborasi peserta didik dalam Pendidikan Pancasila dan Kewarganegaraan (PPKn). Penelitian ini menggunakan metode penelitian tindakan kelas dengan pendekatan kualitatif dan kuantitatif. Tahapan dalam penelitian ini, yaitu: perencanaan, pelaksanaan, observasi, dan refleksi. Data penelitian diperoleh menggunakan instrumen monitoring kegiatan guru dan instrumen monitoring kegiatan peserta didik. Hasil penelitian penerapan pembelajaran jigsaw dalam PPKn mampu meningkatkan keterampilan kolaborasi peserta didik, yaitu: pada siklus I diperoleh katagori cukup(58\%) dan siklus II diperoleh katagori baik $(78 \%)$. Penerapan model ini juga mampu mengembangkan suasana pembelajaran yang kolaboratif.
\end{abstract}

Kata Kunci: Jigsaw; Keterampilan Kolaborasi; PPKn.

\begin{abstract}
In classroom learning practices, many teachers use learning methods and conditions that are analogous to saving activities and a competition system, so to overcome these problems, jigsaw learning is applied to improve student collaboration skills in Pancasila and Citizenship Education (PPKn). This study uses a classroom action research method with qualitative and quantitative approaches. The stages in this research are planning, implementing, observing and reflecting. The research data were obtained using teacher activity monitoring instruments and student activity monitoring instruments. The results of the research on the application of jigsaw learning in PPKn were able to improve the collaboration skills of students, namely: in the first cycle there was a sufficient category (58\%) and the second cycle obtained a good category (78\%). The application of this model is also able to develop a collaborative learning atmosphere.
\end{abstract}

Keywords: Jigsaw; Collaboration Skills; PPKn.

\section{PENDAHULUAN}

Pada abad 21, setiap peserta didik sejatinya mendapatkan pendidikan yang efektif yang dapat memenuhi empat keterampilan yaitu: berkomunikasi, berkolaborasi, bernalar kritis dan mampu memecahkan permasalahan, dan kreatif dan berinovasi (Binkley 2012).

Dari beberapa keterampilan tersebut, kolaborasi merupakan aspek keterampilan yang penting untuk mencapai hasil yang efektif (Fitriyani et al., 2019). Betapa pentingnya peserta didik memiliki keterampilan kolaboratif disertai perasaan senang ketika bersama orang lain dan bersikap baik pada orang lain (Kementerian Pendidikan dan Kebudayaan, 2020).

Menurut Taryono (2019) bahwa keterampilan kolaborasi peserta didik perlu memenuhi enam komponen yaitu: (1) tanggung jawab; (2) membantu tim; (3) menghormati orang lain, (4) membuat dan mengikuti perjanjian, (5) mengelola pekerjaan, dan (6) bekerja sebagai tim. Sedangkan Redhana (2019) menyatakan bahwa keterampilan kolaborasi perlu 
ditunjukkan dengan kemampuan sebagai berikut: (1) bekerja secara tepat dan menghargai anggota kelompok, (2) menampilkan fleksibilitas dan keinginan untuk menjadi orang yang bermanfaat dalam melaksanakan diskusi untuk tujuan bersama, dan (3) bertanggung jawab dalam tugas-tugas kolaboratif dan menghormati pemikiran setiap anggota kelompok.

Mengkonstruksi Peserta didik yang memiliki keterampilan kolaborasi membutuhkan metode pembelajaran yang efektif. Namun saat ini pembelajaran yang dilakukan para guru di sebagian besar sekolah masih berjalan apa adanya yang mana pembelajarannya masih memindahkan pengetahuan dari guru kepada peserta didik. Seperti yang disampaikan Indrajati dalam (Slam, 2020) bahwa banyak guru memakai metode dan suasana pembelajaran yang dianalogikan seperti aktivitas "menabung”. Tugas guru memberikan materi ajar dan mengharapkan peserta didik untuk menghapal dan mengingatnya. Seharusnya pembelajaran adalah suatu aktivitas yang dilakukan peserta didik, bukan sesuatu yang dilakukan terhadap peserta didik.

Selain metode "menabung", para guru juga sering menerapkan pembelajaran kompetisi. Nasution dalam (Slam, 2015) menyatakan kelemahan-kelemahan pembelajaran kompetisi,yaitu:(1)pesertadidik melaksanakan kompetisi untuk memperoleh angka atau pujian perorangan; (2) kompetisi bisa mengakibatkan perselisihan dalam kelas yang akan menimbulkan suasana hubungan antara peserta didik yang kurang harmonis; (3) yang menang dalam kompetisi merasa dirinya terhebat dan menganggap yang lain pecundang. Sikap tersebut merendahkan kepribadian peserta didik sendiri; (4) yang gagal kompetisi akan merasa Frustasi dan rendah diri. Dengan pembelajaran semacam itu juga akan menyulitkan guru untuk mengkonstruksi peserta didik yang kolaboratif.
Misi keterampilan warga negara dunia dalam menghadapi tantangan kontemporer ini dan mendatang menjadi penting untuk perubahan konsep pendidikan kewarganegaraan bagi warga negara abad 21. Oleh karena itu, perlu dipersiapkan karakteristik warga negara yang mampu berkolaborasi dengan orang lain dan bertanggung jawab.

Berdasarkan persoalan pembelajaran tersebutdanperlunyapeningkatanketerampilan kolaborasi peserta didik, memerlukan metode pembelajaran yang efektif. Pendidikan Pancasila dan Kewarganegaraan (PPKn) dengan pembelajaran jigsaw berpengaruh signifikan terhadap peningkatan kompetensi kewarganegaraan peserta didik (Slam, 2014). Pembelajaran jigsaw dalam PPKn mampu meningkatkan mutu proses dan hasil pembelajaran (Elyawati, 2018).

Menurut Shoimin, (2018) dengan pembelajaran jigsaw, peserta didik berkolaborasi saling ketergantungan positif dan bertanggung. jawab secara perseorangan. Sedangkan Rusman (2010) mengemukakan bahwa dalam pembelajaran jigsaw ini peserta didik mendapat banyak peluang menyampaikan pendapat dan mengelola informasi dan dapat meningkatkan keterampilan komunikasi.

Jannah et al. (2019) mengemukakan bahwa pembelajaran jigsaw sebagai model pembelajaran yang melibatkan beberapa peserta didik dalam satu tim (tim ahli) yang bekerja sama dalam membahas materi ajar tertentu dan menguasainya serta bertanggung jawab untuk membelajarkan materi tersebut ke tim asal.

Lebih lanjut Istarani (2014) mengemukakan 8 langkah pembelajaran jigsaw, yaitu: (1) Peserta didik dikelompokkan menjadi kurang lebih empat orang (2) Tiap orang dalam tim diberi bahan ajar yang berbeda. (3) Anggota dari tim yang berbeda dengan penugasan yang sama (4) Pasca pembahasan sebagai tim ahli setiap anggota kembali ke tim asal dan secara bergantian menyampaikannya 
materi ajar kepada seluruh anggota tim asal dan tiap anggota lainnya menyimaknya. (5) Tim asal mempresentasikan hasil pembahasannya. (6) Guru melaksanakan evaluasi. (7) Penutup dengan refleksi dan tindak lanjut.

Manfaat pembelajaran jigsaw bila diterapkan secara efektif, maka peserta didik akan mampu: (1) bekerjasama yang baik; (2) mengembangkan komunikasi di dalam kelas; (3) menyimak pendapat-pendapat orang lain dan berkomunikasi secara baik; (4) meningkatkan akademik, kemandirian, dan belajar kepedulian terhadap sekolah; (5) bergotong-royong serta peduli terhadap orang lain; dan (6) mengontrol pengaruh negatif dan pertentangan. (Afriyanto \& Budimansyah, 2013).

PPKn (Pendidikan Pancasila dan Kewarganegaraan) sebagai mata pelajaran, dengan misi menumbuhkan karakter Pancasila, yakni menjadi warga negara yang demokratis dan bertanggung jawab. Dalam konteks kehidupan global, PPKn juga perlu membekali peserta didik agar mampu hidup dalam kehidupan kebhinekaan global sebagai warga dunia (global citizenship) (Kementerian Pendidikan dan Kebudayaan, 2016). PPKn memiliki visi sebagai wahana substantif, pedagogis, dan sosial budaya untuk membangun cita-cita, nilai, konsep, prinsip, sikap, dan keterampilan demokrasi dalam diri warga negara dalam berbangsa dan bernegara kebangsaan Indonesia (Winataputra, 2012). Oleh karena itu, peserta didik efektif dibekali keterampilan kolaborasi melalui pembelajaran jigsaw dalam PPKn. Hal tersebut selaras dengan tujuan PPKn salah satunya keterampilan kewarganegaraan(Kementerian Pendidikan dan Kebudayaan, 2015).

Berkaitan dengan hal-hal tersebut di atas, tujuan penelitian ini adalah untuk mengetahui peningkatan keterampilan kolaborasi peserta didik dengan pembelajaran jigsaw dalam PPKn.

\section{METODE}

Penelitian ini menggunakan pendekatan kualitatif dan kuantitatif. Menurut Creswell dalam (Darmadi, 2013), pendekatan kualitatif ini, peneliti membuat suatu gambaran kompleks, meneliti kata-kata, laporan terinci dan pandangan responden, dan melakukan studi pada situasi yang alami.

Moleong (2007) mengatakan bahwa pendekatan kuantitatif digunakan untuk menjelaskan penyebab fenomena sosial melalui pengukuran objektif dan analisis numerikal. Pendekatan kuantitatif adalah suatu pendekatan yang hasilnya berupa angka-angka untuk membandingkan sejauh mana peningkatan yang terjadi.

Metode penelitian yang digunakan adalah Penelitian Tindakan Kelas (PTK) yang bertujuan untuk memperbaiki dan atau meningkatkan mutu pembelajaran di kelas. Lebih khusus Suharsimi dalam (Depdiknas, 2008; Daryanto, 2011) menjelaskan bahwa penelitian tindakan kelas merupakan paparan gabungan definisi dari tiga kata, yaitu "penelitian, "tindakan", dan "kelas". Penelitian adalah kegiatan mencermati objek tertentu yang hati-hati dan kritis dalam mencari fakta dan prinsip-prinsip menurut metode objektif yang jelas untuk menemukan data yang berguna yang berkepentingan dan peneliti. Tindakan berarti kegiatan yang bertujuan tertentu yang pelaksanaannya berbentuk siklus kegiatan. Kelas adalah peserta didik yang belajar tidak hanya terbatas dalam sebuah ruangan kelas saja, melainkan dapat juga ketika peserta didik sedang melakukan karya wisata, praktikum di laboratorium, atau belajar di tempat lain di bawah arahan guru. Dalam hal ini kelas bukan wujud ruangan tetapi diartikan sebagai sekelompok peserta didik yang sedang belajar.

Menurut Cohen et al. (2007) bahwa proses penelitian tindakan kelas bersifat siklus dimana dalam satu siklus terdiri dari empat tahapan utama: perencanaan, 
pelaksanaan, observasi dan refleksi. Penelitian tindakan ini dilaksanakan selama dua siklus, setiap siklus merupakan rangkaian kegiatan yang saling berkaitan. Artinya pelaksanaan siklus kedua merupakan kelanjutan dan perbaikan dari pelaksanaan siklus kesatu.

Subyek penelitian ini adalah seluruh peserta didik kelas IX D berjumlah 28 orang, yang terdiri atas 14 orang perempuan dan 14 orang laklaki.

Lokasi penelitian ini mengenai pembelajaran jigsaw dalam PPKn untuk meningkatkan keterampilan kolaborasi peserta didik dilaksanakan di SMPN 3 Majalengka Kabupaten Majalengka Provinsi Jawa Barat.

\section{HASIL DAN PEMBAHASAN}

\section{Hasil Penelitian Siklus Pertama}

\section{a. Merencanakan Pembelajaran}

\section{Jigsaw Siklus Pertama}

Perencanaan siklus pertama adalah sebagai berikut: (1) peneliti bersama-sama guru PPKn melakukan diskusi membahas rencana pelaksanaan pembelajaran yang mengadaptasi pembelajaran jigsaw; (2) menyiapkan format lembar observasi aktivitas guru, dan lembar observasi aktivitas peserta didik; dan instrumen penilaian keterampilan kolaborasi peserta didik (3) menyiapkan buku sumber. Hal ini dilakukan agar ketercapaian hasil pembelajaran jigsaw dalam PPKn dapat terukur.

\section{b. Melaksanakan Pembelajaran Jigsaw Siklus Pertama}

Hasil observasi terhadap pembelajaran jigsaw siklus pertama adalah sebagai berikut.

\section{Kegiatan Pendahuluan}

Kegiatan pendahuluan, pertama, guru memberi salam dan berdoa bersama sesuai agamanya masing-masing. Kedua, guru melakukan setting ruangan dan kesiapan belajar peserta didik secara fisik maupun psikologis. Ketiga, guru bertanya pada peserta didik mengenai materi ajar dan mengaitkan dengan skemata, selanjutnya mengajukan pertanyaan menantang dan menyampaikan manfaat materi ajar dalam kehidupan. Keempat, guru menyampaikan tujuan atau kompetensi yang hendak dicapai baik aspek pengetahuan, sikap, dan keterampilan dengan bahasa peserta didik. Kelima, guru menyampaikan garis besar cakupan materi "Berbudi Pekerti yang Luhur sesuai dengan Pancasila". Keenam, guru meminta peserta didik duduk berkelompok lima sampai enam orang secara beragam (kemampuan akademik, gender, sosial, ekonomi, agama dan ras). Ketujuh, guru mendorong antusias peserta didik mengerjakan tugas-tugas belajar perorangan maupun tim.

\section{Kegiatan Inti}

Kegiatan inti pembelajaran, yaitu: pertama, guru menyajikan materi ajar kepada peserta didik dengan metode ceramah. Kedua, guru mengatur peserta didik ke dalam tim-tim, Peserta didik mendapat penjelasan guru cara terbaik membentuk tim belajar dan membimbing tim belajar beradaptasi yang efektif. Mereka dikelompokkan dengan lima sampai enam anggota yang heterogen yang disebut tim asal. Membantu tim asal dalam menentukan anggota tim ahli, selanjutnya tim ahli dari tiap-tiap tim asal bergabung membentuk tim ahli masing-masing. Pasca para tim ahli membahas materi, tiap anggota tim ahli kembali ke tim asal masing-masing dan menjelaskan hasil pembahasan di tim ahli kepada semua anggota tim asal secara bergantian tentang materi yang mereka kuasai.

Ketiga, guru membimbing peserta didik mengerjakan tugas-tugasnya baik di tim asal maupun di tim ahli. Keempat, guru mengevaluasi proses dan hasil kerja tim dan hasil kolaborasi mereka agar selanjutnya bisa berkolaborasi dengan lebih efektif. Kelima, guru menyampaikan 
reaward atas prestasi belajar perseorangan dan tim. Selanjutnya guru menugaskan peserta didik meresume materi ajar.

\section{Penutup}

Guru dan peserta didik menyimpulkan materi ajar dan merefleksi pembelajaran jigsaw.

\section{c. Melaksanakan Observasi}

\section{Pembelajaran Jigsaw Siklus Pertama}

Kegiatan observasi pembelajaran

Jigsaw dilaksanakan oleh observer (peneliti) berorientasi pada kinerja jigsaw baik yang dilakukan peserta didik maupun guru.

Secara keseluruhan, pelaksanaan pembelajaran jigsaw siklus pertama belum maksimal, yaitu:

Pertama, tahap penyampaian tujuan pembelajaran. guru menyampaikan tujuan pembelajaran yang akan dicapai, sebagian besar peserta didik menyimak dan sebagian kecil acuh tak acuh. Guru memberi motivasi pada peserta didik dan mereka motivasi agar mereka lebih giat belajar dan sikap-sikap yang harus ditumbuhkan untuk terjadinya kolaborasi dalam tim belajar yang majemuk, seperti saling membantu, bertoleransi, saling berteposeliro, dan terbuka.

Kedua tahap menyajikan bahan ajar, guru menyampaikan bahan ajar dan peserta didik menyimaknya. Beberapa peserta didik tidak fokus dan bersenda gurau. Guru dominan ceramah dan sesekali tanya jawab. Guru menjelaskan cara pembelajaran Jigsaw dan kolaborasi yang akan dikembangkan.

Ketiga, guru mengatur peserta didik ke dalam tim-tim, mereka membentuk tim belajar sesuai dengan arahan guru dengan melaksanakan penyesuaian. Mereka berada dalam tim jigsaw (tim asal) terdiri 5-6 peserta didik yang beragam. Peserta didik berada di tim asal masing-masing berjumlah lima tim, kemudian peserta didik ahli dari tiap tim untuk bergabung membentuk tim ahli. Setelah membahas bahan ajar di tim ahli, tiap anggota kembali ke tim asal dan menjelaskan kepada anggota tim asal bahan ajar yang dikuasai. Ketika pembentukan tim dan pembahasan bahan ajar baik di tim asal maupun tim ahli kelihatan sebagian peserta didik masih lamban, canggung, dan kurang antusias..

Keempat, tahap pembimbingan tim belajar dan bekerja baik di tim asal maupun tim ahli. Pada tahap ini pembimbingan tim oleh guru baik di tim asal maupun di tim ahli kelihatannya belum maksimal karena adanya keterbatasan waktu akibatnya masih banyak peserta didik masih acuh tak acuh.

Kelima, guru melakukan evaluasi hasil belajar tentang bahan ajar yang telah dipelajari atau masing-masing tim mempresentasikan hasil kerjanya. Namun guru kurang objektif dalam melaksanakan penilaian peserta didik.

Keenam, guru memberikan reward pada peserta didik yang didasarkan pada kinerja tim dan kinerja perseorangan.

Guru nampaknya sedikit kesulitan dalam melaksanakan langkah-langkah pembelajaran jigsaw. Hal ini karena terbatasnya waktu untuk menyampaikan aturan main pembelajaran jigsaw, media dan bahan ajar yang mengakibatkan belum maksimalnya pembelajaran jigsaw ini.

Tabel 1 Hasil observasi keterampilan kolaborasi peserta didik pada siklus I

\begin{tabular}{lcc}
\hline \multicolumn{1}{c}{ Ketrampilan Kolaborasi } & Jumlah & Persentase \\
\hline Kontribusi & 16 & $57 \%$ \\
Manajemen waktu & 15 & $54 \%$ \\
Memecahkan masalah & 17 & $61 \%$ \\
Bekerjasama dengan orang lain & 19 & $68 \%$ \\
Melakukan penyelidikan & 14 & $50 \%$ \\
\hline \multicolumn{1}{c}{ Rata-rata } & & $58 \%$ \\
\hline
\end{tabular}


Secara grafis dapat dilihat peningkatan keterampilan kolaborasi pada Gambar 1.

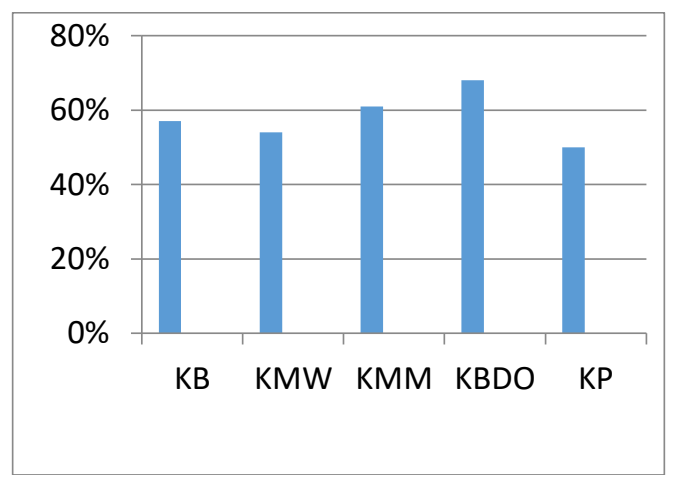

Gambar 1 Grafik Peningkatan Keterampilan Kolaborasi Peserta Didik Siklus I

\section{d. Melaksanakan Refleksi Pembelajaran Jigsaw Siklus Pertama}

Penerapan pembelajaran jigsaw siklus I perlu diperbaiki pada siklus II. Peneliti berserta guru PPKn menyetujui beberapa saran tersebut adalah: (a) Penyampaian tujuan pembelajaran dan motivasi pada peserta didik, perlu lebih bervariasi dan tidak hanya menyampaikan tujuan pembelajaran tidak hanya pada aspek pengetahuan semata, tetapi aspek sikap (sikap spiritual dan sikap sosial) dan juga aspek keterampilan. Dalam memotivasi belajar terhadap peserta didik perlu dilaksanakan secara lisan, tulisan dan visual agar mereka antusias dan memiliki good character baik di tim asal maupun di tim ahli, yakni sikap saling bertoleransi, berteposeliro, terbuka, menolong, bergotong royong, bermusyawarah dan mufakat. Guru perlu menyampaikan pada peserta didik agar menjadi penyimak yang baik pada guru atau orang lain yang sedang berbicara; (b) Guru perlu lebih bervariasi dalam pemberian materi ajar dengan menggunakan metode ceramah yang divarisikan dengan tanya jawab dengan porsi seimbang agar tidak ngantuk dan boring. Guru perlu melakukan langkah-langkah seperti mengoptimalkan pemahaman pada peserta didik semisal dengan peta konsep, pemberian contoh nyata, analogi dan dukungan media audio visual serta meminta peserta didik untuk meringkas bahan ajar; (c.) Guru perlu mengatur peserta didik ke dalam tim-tim baik ke tim asal maupun ke tim ahli secara bervariasi, yaitu membagi peserta didik dalam tim asal menjadi lima tim yang terdiri dari lima hingga enam orang. Guru perlu menugaskan peserta didik dalam timnya untuk membuat suara binatang. Tim satu dengan suara ayam jantan, Tim dua dengan suara bebek, tim tiga dengan suara burung, tim empat dengan suara kucing, dan tim lima dengan suara harimau; (d) Guru perlu lebih fokus dalam membimbing pada tim-tim ahli dalam mengerjakan tugas-tugasnya. Guru perlu mendorong para peserta didik mampu mengerjakan tugas dengan baik di tim ahli. Guru juga perlu menggiring bahwa setiap peserta didik di setiap tim ahli kembali ke tim asal dengan membawa hasil pembahasannya. Kemudian guru mendampingi para peserta didik untuk dapat menjelaskan hasil belajar di tim asal. Setelah tiap-tiap peserta didik melaporkan hasil belajar di tim asal, guru selanjutnya mendampingi peserta didik belajar di tim asal untuk mendiskusikan kembali hasil-hasil belajar tim ahli. Guru perlu menyampaikan bahwa hasil belajar di tim asal ini sebagai bahan untuk dipresentasikan oleh tiap-tiap tim asal; (e) Guru perlu melaksanakan evaluasi proses kinerja tim dan hasil kerjasama peserta didik. Dalam melakukan tugas ini guru perlu menggunakan instrumen penilaian kinerja tim dalam rangka objektivitas; (f) Guru perlu memberikan reward kepada tim berdasarkan kinerja tim. Tim yang luar biasa dikatakan "excellent group", Tim yang sangat baik dikatakan "very good group", tim yang baik dikatakan "good group", tim harapan pertama dikatakan “ the first hopping group", tim harapan kedua disebut "the second hopping group".

Dengan adanya kekurangan dalam 
proses pembelajaran jigsaw dan hasil belajar peserta didik belum mencapai target yang diharapkan, maka diperlukan pelaksanaan pembelajaran jigsaw siklus II dengan beberapa perbaikan.

\section{Hasil Penelitian Siklus Kedua}

\section{a. Merencanakan Pembelajaran}

\section{Jigsaw Siklus Kedua}

Perencanaan siklus kedua adalah sebagai berikut: (1) peneliti bersamasama guru PPKn melakukan revisi rencana pelaksanaan pembelajaran yang mengadaptasi pembelajaran jigsaw; (2) menyiapkan format lembar observasi aktivitas guru, dan lembar observasi aktivitas peserta didik; dan instrumen penilaian keterampilan kolaborasi peserta didik (3) menyiapkan buku sumber. Hal ini dilakukan agar ketercapaian hasil pembelajaran jigsaw yang dilaksanakan guru PPKn bersama peneliti dapat terukur; (4) Melaksanakan perbaikan teknik mengkonstruksi semangat dan motivasi di awal pembelajaran.

Perbaikan rencana pelaksanaan pembelajaran akan guru gunakan dalam pembelajaran siklus kedua.

\section{b. Melaksanakan Pembelajaran Jigsaw Siklus Kedua}

\section{Kegiatan Pendahuluan}

Kegiatan pendahuluan, yaitu:

Guru memberi salam dan menugaskan kepada ketua kelas untuk memimpin doa bersama sesuai agamanya masingmasing; (2) Guru melakukan setting ruangan dan kesiapan belajar peserta didik secara fisik maupun secara psikologis; (3) Guru bertanya terkait materi ajar dan mengaitkan dengan skemata ini agar bahan ajar ini lebih bernilai, selanjutnya guru mengajukan pertanyaan menantang dan menyampaikan manfaat bahan ajar dalam kehidupan keseharian; (4) Guru menyampaikan tujuan pembelajaran; (5) Guru menyampaikan garis besar cakupan materi; (6) Guru meminta peserta didik duduk berkelompok lima sampai enam orang; (7) Guru memotivasi peserta didik agar lebih antusias dalam mengerjakan tugas-tugas belajar perseorangan maupun tim.

\section{Kegiatan Inti}

Kegiatan inti pembelajaran, yaitu: pertama, kegiatan menyajikan materi ajar, guru bervariasi dalam pemberian materi. Guru menggunakan metode ceramah yang divariasikan dengan tanya jawab dengan porsi seimbang. Guru memaksimalkan pemahaman materi ajar terhadap peserta didik dengan peta konsep, pemberian contoh nyata, dan analogi serta dukungan media audio visual serta meresume bahan ajar.

Kedua, Guru melakukan pengaturan peserta didik lebih bervariasi ke dalam timtim baik tim asal maupun tim ahli, yaitu membagi peserta didik dalam tim asal menjadi lima tim yang terdiri dari lima hingga enam orang. Guru menugaskan kepada peserta didik dalam timnya untuk membuat suara binatang. Tim satu dengan suara ayam jantan, tim dua dengan suara bebek, tim tiga dengan suara burung, tim empat dengan mengeluarkan suara kucing, dan tim lima dengan suara harimau. Materi ajar pertama diberikan kepada peserta didik yang nomor absen pertama, sedangkan peserta didik yang nomor absen kedua menerima bagian materi ajar yang kedua dan seterusnya.

Ketiga, guru melaksanakan bimbingan yang lebih fokus pada tim-tim ahli ketika mengerjakan tugas-tugasnya. Guru mendorong para peserta didik agar mampu mengerjakan tugas dengan baik di tim ahli. Guru juga mendorong bahwa setiap peserta didik di setiap tim ahli kembali ke tim asal dengan menguasai bahan ajarnya. Selanjutnya guru mendampingi setiap peserta didik untuk mampu menyampaikan hasil belajar di tim asal. Setelah tiap-tiap peserta didik menyampaikan hasil belajar di tim asal secara bergantian, 
guru selanjutnya mendampingi peserta didik belajar ditimnya untuk mendiskusikan atau membahas kembali hasil-hasil belajar tim ahli. Selanjutnya guru menyampaikan bahwa hasil belajar di tim asal ini sebagai bahan presentasi untuk setiap tim asal dan setiap tim asal mempresentasikannya.

Keempat, guru melaksanakan evaluasi kinerja tim dan hasil kerjasama peserta didik. Dalam menjalankan tugas ini guru memakai instrumen penilaian kinerja tim.

Kelima, Guru memberikan reward kepada tim berdasarkan kinerja tim. Tim yang luar biasa dikatakan "excellent group", Tim yang sangat baik dikatakan "very good group", Tim yang baik dikatakan "good group", Tim harapan satu dikatakan "the first hopping group", tim harapan dua disebut "the second hopping group".

\section{Penutup}

Dalam kegiatan penutup, guru dan peserta didik membuat simpulan bahan ajar yang dicapai. Peserta didik merefleksikan pengalaman belajar.

\section{c. Melaksanakan Observasi \\ Pembelajaran Jigsaw Siklus Kedua}

Hasil observasi oleh observer (peneliti) pada pembelajaran jigsaw PPKn siklus kedua mengalami peningkatan, khususnya pada kinerja peserta didik dan guru.

Pada saat bertatap muka dan berdiskusi berlangsung partisipasi peserta didik mengalami peningkatan dibandingkan dengan partisipasinya pada siklus pertama. Para peserta didik juga memiliki motivasi yang tinggi dalam melakukan kegiatan diskusi di tim asal maupun di tim ahli. Keaktifan ini juga ditunjukkan ketika presentasi setiap tim asal di depan kelas. Perbedaan yang sangat tampak dari pembelajaran jigsaw siklus pertama adalah peningkatan keterampilan kolaborasi peserta didik. Hal ini dapat diketahui dari penampilan peserta didik dalam pengambilan keputusan secara bersama-sama, berkomunikasi, belajar menjadi pemimpin tim dan dipimpin, membangun rasa percaya diri, menumbuhkan tanggung jawab perseorangan dan tim, dan menyelesaikan persoalan.

Demikian juga pada aktivitas dan penampilan guru ada peningkatan yang signifikan, baik dalam penyampaian tujuan pembelajaran dan motivasi terhadap peserta didik, menyampaikan materi ajar, membimbing pesertadidikdalammengerjakantugas-tugastim baik di tim asal maupun tim ahli dibandingkan dengan aktivitas dan penampilannya pada kegiatan pembelajaran jigsaw siklus pertama. Peningkatan aktivitas dan penampilan guru dapat diketahui dari peserta didik memiliki banyak kesempatan untuk mengemukakan pendapat dan mengolah informasi yang didapat dan dapat meningkatkan keterampilan berkomunikasi, anggota tim bertanggung jawab atas keberhasilan timnya dan ketuntasan bahan ajar yang dipelajari dan mampu menyampaikan informasinya kepada tim asal. Peserta didik dalam pembelajaran jigsaw siklus kedua ini menghadirkan hasil belajar lebih baik, sikap yang lebih baik dan juga lebih positif terhadap pembelajaran ini, di samping saling menghargai perbedaan dan pendapat orang lain.

Hasil observasi terhadap pembelajaran jigsaw ininampak bahwa pembelajaran jigsaw pada siklus kedua mampu meningkatkan keterampilan kolaborasi peserta didik dalam PPKn.

Tabel 2 Hasil observasi keterampilan kolaborasi peserta didik pada siklus II

\begin{tabular}{lcc}
\multicolumn{1}{c}{ Ketrampilan Kolaborasi } & Jumlah & Persentase \\
\hline Kontribusi & 22 & $79 \%$ \\
Manajemen waktu & 21 & $75 \%$ \\
Memecahkan masalah & 23 & $82 \%$ \\
Bekerjasama dengan orang lain & 24 & $86 \%$ \\
Melakukan penyelidikan & 20 & $71 \%$ \\
\hline \multicolumn{1}{c}{ Rata-rata } & & $78 \%$ \\
\hline
\end{tabular}


Secara grafis dapat dilihat peningkatannya pada grafik 2 .

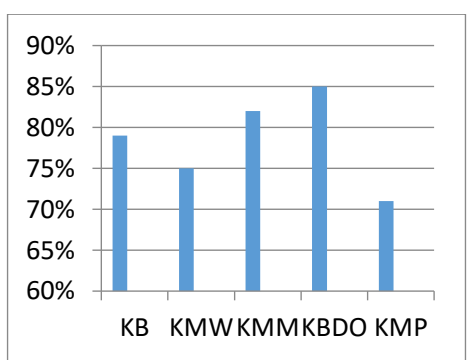

Gambar 2 Grafik Peningkatan Keterampilan Kolaborasi Peserta Didik Siklus II

Hasil pembelajaran jigsaw siklus kedua ini menunjukkan peningkatan dengan ketercapaian keterampilan kolaborasi peserta didik mencapai katagori baik (78\%).

\section{d. Melaksanakan Refleksi Pembelajaran Jigsaw Siklus Kedua}

Pasca pembelajaran jigsaw pada siklus kedua ini, peneliti bersama guru PPKn serta perwakilan peserta didik melaksanakan refleksi terkait penerapan pembelajaran jigsaw siklus kedua. Beberapa kelebihan atau sisi kurangnya penerapan pembelajaran jigsaw siklus kedua ini dideskripsikan sebagai berikut. Pengakuan peserta didik yang menyatakan bahwa pembelajaran jigsaw ini menarik dan menyenangkan. Sebab di samping banyak kesempatan untuk berdiskusi, mereka mengaku mendapatkan model belajar yang bisa mengembangkan tanggung jawab perseorangan maupun tim, percaya diri, pengambilan keputusan, kepemimpinan, dan menyelesaikan masalah. Ketika para peserta didik berkeinginan untuk meraih sebuah tujuan bersama, membuat mereka mengekpresikan norma-norma yang baik. Telah terjadinya peningkatan minat dan motivasi belajar peserta didik dengan pembelajaran jigsaw telah terjawab melalui pengakuan refleksi ini.

Guru PPKn merasakan ada hal kebaruan yang bisa didapatkan dari pembelajaran jigsaw ini, yaitu: (1) meningkatkan keterampilan hidup kolaborasi; (2) meningkatkan perilaku adaptasi sosial yang positif; (3) meningkatkan harga diri peserta didik; (4) meningkatkan sikap peserta didik positif terhadap guru; (5) meningkatkan hubungan antar peserta didik yang heterogen; (6) meningkatkan sikap peserta didik positif terhadap sekolah; (7) mendorong tumbuhnya kesadaran perseorangan; (8) bisa digunakan untuk mencapai tarap berpikir tingkat tinggi; (9) meningkatkan daya nalar; dan (10) meningkatkan mutu proses dan hasil belajar.

Pembelajaran jigsaw mampu memberikan kepada peserta didik, yaitu pengetahuan, sikap, dan keterampilan kolaborasi. Pencapaian hasil belajar telah memenuhi target penelitian, dengan demikian penelitian tindakan kelas ini dianggap berhasil, sehingga tidak dilanjutkan lagi pada siklus berikutnya.

Berdasarkan hasil penelitian pembelajaran jigsaw siklus pertama maupun siklus kedua, peneliti membahas dan membandingkan hasilhasil penelitian siklus I dan siklus II sebagai berikut. Keterampilan kolaborasi peserta didik pada siklus I, ketercapaian rata-rata 58\%. Sedangkan keterampilan kolaborasi peserta didik siklus II, ketercapaian rata-rata $78 \%$. Ini berarti bahwa keterampilan kolaborasi pada siklus II naik 20\% atau lebih baik dari pada siklus I seperti tampak pada tabel 3 berikut.

Tabel 3

Perbandingan Keterampilan Kolaborasi Peserta Didik Siklus I dan Siklus II

\begin{tabular}{lc}
\hline \multicolumn{1}{c}{ Ketrampilan } & Kolaborasi \\
\hline Silkus I & $58 \%$ \\
Siklus II & $78 \%$ \\
\hline
\end{tabular}

Perbandingan prosentasi rata-rata keterampilan kolaborasi peserta didik pada siklus I dan siklus II dapat dilihat pada gambar 3 .

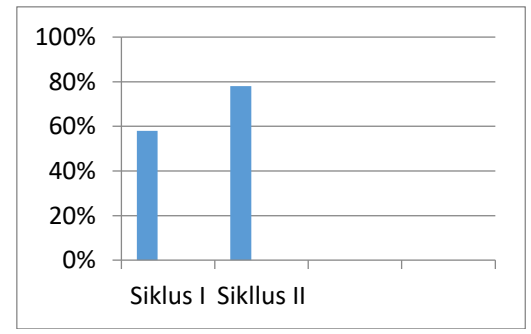

Gambar 3 Grafik Perbandingan Peningkatan Keterampilan Kolaborasi Peserta Didik 
Berdasarkan gambar 3 dapat dilihat bahwa keterampilan kolaborasi peserta didik mengalami peningkatan yang terlihat dari rata-rata siklus I adalah $58 \%$ dan siklus II adalah $78 \%$. Nilai ini menunjukkan keterampilan kolaborasi peserta didik mengalami peningkatan. Pembelajaran jigsaw mampu meningkatkan keterampilan kolaborasi peserta didik dalam PPKn. Hal ini selaras dengan hasil penelitian Anggis (2016), penerapan model pembelajaran kooperatif jigsaw berbasis lesson study dapat meningkatkan keterampilan kolaboratif. Relevan juga dengan hasil penelitian Iryani (2016), pembelajaran sejarah dengan teknik jigsaw dapat meningkatkan hasil belajar siswa.

Selanjutnya Widodo, et al. (2019) mengemukakan hasil penelitiannya bahwa secara klasikal penerapan model pembelajaran jigsaw dengan pendekatan kolaboratif dapat meningkatkan rata-rata prestasi belajar dari 59,4 menjadi 93,9 pada akhir siklus II.

\section{SIMPULAN}

Berdasarkan temuan dan pembahasan hasil penelitian ini, simpulan yang dapat diambil adalah penerapan pembelajaran jigsaw dalam PPKn mampu meningkatkan keterampilan kolaborasi peserta didik.

Untuk itu, disarankan agar pembelajaran jigsaw ini digunakan dalam PPKn untuk meningkatkan keterampilan kolaborasi peserta didik.

\section{DAFTAR PUSTAKA}

Afriyanto dan Budimansyah. (2013). Memahami Pendidikan Nilai dan Pendidikan Karakter Melalui Pembelajaran Seni Gamelan Sunda. Jurnal Penelitian Pendidikan Karakter, 2 (1), 1-7.

Anggis, E.V. (2016). Penerapan Model Kooperatif Jigsaw berbasis Lesson Study untuk Meningkatkan Keterampilan Kolaboratif dan Hasil Belajar Kognitif. Proceeding Biology Education Conference, 13 (1), 493-497.
Binkley, M. at al, (2012). Defining twentyfirst century skills. Assesment and Teaching of $21^{\text {st }}$ Century Skills. Dordrecht: Springer. (Online) 17-66 https://link.springer.com/chapter/ 10.1007/978-94-007-2324-5_2 diakses 18 Sepetember 2020

Cohen, L. et al. (2007). Research Methods In Education. London: Routledge.

Darmadi, H. (2013). Dimensi-Dimensi Metode Penelitian Pendidikan dan Sosial: Konsep Dasar dan Implementasi. Bandung: Alfabeta.

Daryanto. (2011). Penelitian Tindakan Kelas dan Penelitian Tindakan Sekolah. Yogyakarta: Gavameda

Departemen Pendidikan Nasional. (2008). Penelitian Tindakan Kelas. Jakarta: Depdiknas

Elyawati. (2018). Penerapan Model Pembelajaran Kooperative Tipe Jigsaw Untuk Meningkatkan Hasil Belajar PKn Siswa Kelas V SD Negeri Cikijing III Kecamatan Cikijing Kabupaten Majalengka. Jurnal Cakrawala Pendas, 4 (1). 67-73

Fitriani,D. at al.(2019). Penggunaan Problem Based Learning untuk Meningkatkan Keterampilan Kolaborasi dan Berpikir Tingkat Tinggi. Jurnal Bioterdidik Wahana Ekspresi Ilmiah. 7(3), 77-87

Iryani. (2016). Penerapan ModelPembelajaran Jigsaw Untuk Meningkatkan Prestasi Belajar Siswa Dalam Pembelajaran Sejarah Di Kelas XI SMK Negeri 2 Ciamis. Jurnal Pengembangan Profesi, $9(5), 63-80$.

Istarani. (2014). 58 Model Pembelajaran Inovatif. Medan: Media Persada

Jannah, R. at al., (2019). Penerapan Model Cooperative Tipe Jigsaw Untuk Meningkatkan Keaktifan Belajar PPKn Siswa Kelas VII SMP. Jurnal FKIP Untan Pontianak. Jurnal Pendidikan dan Pembelajaran Khatulistiwa, (Online), 19 (4): 1-9, https://jurnal. untan.ac.id/index.php/jpdpb/article/ 
view/40473/75676585795 diakses 15 Januari 2020

Kementerian Pendidikan dan Kebudayaan (2015). Buku Guru Pendidikan Pancasila dan Kewarganegaraan Kelas IX. Jakarta: Kemdikbud.

Kementerian Pendidikan dan Kebudayaan, (2016). Pendidikan Pancasila dan Kewarganegaraan. Jakarta: Kemdikbud. Kementerian Pendidikan dan Kebudayaan. (2020). Profil Pelajar Pancasila. Jakarta: Kemdikbud

Moleong, Lexy (2007). Metode Penelitian Kualitatif. Bandung: Rosda Karya.

Redhana I.W. 2019. Mengembangkan Keterampilan Abad Ke-21 dalam Pembelajaran Kimia. Jurnal Inovasi Pendidikan Kimia, 13 (1), 22392253.

Rusman (2010). Model-Model Pembelajaran. Bandung: Mulia Mandiri Pers.

Shoimin, Aris (2018). 68 Model Pembelajaran Inovatif dalam Kurikulum 2013. Yogyakarta: Ar-Ruzz Media.

Slam, Zaenul. (2010). Penerapan Model Cooperative Learning dan Model Pembelajaran Konvensional Terhadap Peningkatan Hasil Belajar Peserta Didik. Jurnal KKPS NEWS. 1(4), 2844

Slam,Zaenul.(2014).Pengembangan Karakter Kerjasama Berdasarkan Pancasila Melalui Pembelajaran Pendidikan Kewarganegaraan. Disertasi Tidak Diterbitkan. Bandung: Sekolah Pasca Sarjana Universitas Pendidikan Indonesia

Slam, Zaenul. (2015). Profesional Learning Untuk Indonesia Emas. Pembelajaran Gotong Royong Inovatif Berbasis Soft Skill Dan Hard Skill Untuk Mewujudkan Indonesia Emas. Menerbitkan Proceeding Seminar Nasional (Hlm 127-139). Jakarta: UIN Syarif Hidayatullah
Slam,Zaenul. (2020). Menatap Wajah Pendidikan Indonesia Di Era 4.0: Pedagogik Transformatif "Merdeka Belajar" Ki Hajar Dewantoro (Hendri Gunawan). Serang: Desanta Muliavisitama Taryono, (2019). Penerapan Pembelajaran Berbasis Proyek dan Pembelajaran Berbasis Masalah Pada Mata Pelajaran Fisika Untuk Meningkatkan Keterampilan Abad 21 Siswa SMP. Jurnal Wahana Pendidikan Fisika, 4 (1), 89-105.

Widodo, SA. (2019). Peningkatan Hasil Belajar Dengan Menggunakan Pembelajaran Kolaboratif Tipe Jigsaw. Jurnal Prisma, 8 (2). 111- 123

Winataputra (2012). Transformasi Nilai-Nilai Kebangsaan Untuk memperkokoh Jati Diri Bangsa Indonesia: Suatu Pendekatan Pendidikan Kewarganegaraan. Bandung: CV Maulana Media Grafika 